\title{
Covert Action Failure and Fiasco Construction: William Hague's 2011 Libyan Venture
}

\section{Rory Cormac and Oliver Daddow}

\begin{abstract}
In 2011 William Hague, then British Foreign Secretary, authorized a Special Forces team to enter Libya and attempt to contact rebels opposed to Muammar Gaddafi in the unfolding civil war. However, its members were detained by the rebels, questioned and ejected from the country. This article puts the literature on public policy failures into dialogue with that on covert action as a tool of foreign policy. It asks: why did this not develop into a fully-fledged policy fiasco when journalists and politicians alike judged it to have been a major error of judgement on Hague's part? Using narrative analysis of the contemporary reporting of this incident, we argue that the government - possessing the advantage of information asymmetry accruing from operational secrecy - was ultimately able to win the battle of narratives in a frame contestation process. The study of information asymmetry can enhance the recently revivified research into foreign policy failures.
\end{abstract}

KEY WORDS British foreign policy; covert action; discourse; failure; fiasco; narrative analysis;

\section{Introduction}

Covert action is one of the most controversial means of executing government policy, a highrisk option fraught with inherent dangers. Given this, it might be assumed all too easily that whenever covert actions turn sour, which many do, apparent failure can swiftly escalate into 
full-blown fiasco. However, even if a covert action is judged to have failed, secrecy and operational security may well prevent failure developing into fiasco. This creates an interesting paradox, wherein some of the most controversial foreign policy ventures that go wrong can avoid becoming fiascos when less controversial domestic public policies may well do (see the number of domestic 'blunders' cited in King and Crewe 2013). The goal of this article is to investigate the narrative construction of covert action fiascos, a fiasco 'type' which has been sorely neglected in the emerging research programme on foreign policy fiascos.

Our choice of case study is Britain's attempt to insert a secret team into Libya in March 2011, at the height of the Arab Spring. We investigate the ways in which participants in accountability forums in politics and the media attempted to construct a fiasco, but ultimately failed to do so. Our argument is that Foreign Secretary William Hague - the character in the drama deemed most blameworthy by most commentators - was narrowly able to avoid the perceived failure becoming a fiasco. This, we find, was the result both of Hague's actions in defusing fiasco narratives and of contingency surrounding shifting media agendas. Most significantly, however, was the clear information asymmetry at work. The secrecy of the operation prevented critics from mobilizing behind an unassailable fiasco narrative built on firm empirical foundations, that might have gained traction in the public mind. Moreover, the government ran an effective message management campaign. It downplayed the salience of the operation while stressing the imperative of a bold and united British response to the Arab Spring. Helpfully for Hague, the government's wider Libyan strategy did not at this point prove politically contentious. Ultimately, therefore, the Foreign Secretary survived in office, was backed by the Prime Minister and Cabinet colleagues not known to be naturally sympathetic to him (a materially significant political element) and, arguably most importantly, he managed to win the battle of 'frames' by having his version of events come to be accepted as the dominant one. For these reasons, we deem this episode to have been an attempted fiasco 
construction that failed. The article offers novel insights into the conceptual and practical challenges associated with the study of covert action fiascos. Even more than this, however, it helps us appreciate the challenges of studying foreign and domestic policy fiascos more widely.

The article proceeds in three parts. In the first part we review the two literatures we bring together: the public policy evaluation literature and that on covert action, with a view to explaining the benefits to be garnered from linking the two. The second part defines the key terms such as 'fiasco' and shows empirically the opportunities and challenges of studying covert action using this conceptual toolkit. The third part presents our method and discusses the main evidence from the Libya case study. The conclusion reflects on the key contributions our article makes to the recently revivified research into foreign policy failures, and to the study of lessons learned from foreign policy failures.

\section{State of the art: Public policy analysis and foreign policy failures}

This article benefits from putting two sets of literature into conversation, with the aim of advancing a major new body of research into foreign policy failures. The first is the public policy evaluation literature focusing on the study of fiascos and policy failures, of all types, strengths and legacies. Since the publication of Mark Bovens and Paul 't Hart's seminal work (1996; 2001), this field has been dominated by discussions of domestic policy fiascos written with a public administration audience in mind. Typical examples include 'overspend' fiascos such as the UK Millennium Dome project and the building of the Sydney Opera House; failures to deal with crises, such as the UK government's response to the BSE outbreak in the late 1990s; and high profile tragedies, such as the Hillsborough football stadium disaster in April 1989. These have all been judged fiascos either of overall policy, programme or procedurally (see 
McConnell 2010a; McConnell 2016; Howlett 2012). Ongoing work developing a framework for understanding and explaining policy failure has been complemented by close analysis of policy successes - again largely from a domestic public policy perspective - which have tightened our understanding of the obverse case of the policy fiasco (see for example Marsh and McConnell 2010; McConnell 2010b).

The second body of literature deployed in this article is that on covert action. The historiography in this field has, hitherto, been dominated by linear narratives and countryspecific case studies (the standard bearer on UK covert action being Aldrich 2001). Much of this belongs to a pioneering first generation corpus using archival research to reveal operations. Accompanying this, there are many works considering specific covert actions deemed to have failed, notably the Bay of Pigs (Rasenberger 2012) and the Iran-Contra affair (Byrne 2014). These are all insightful studies. However, they lack a comprehensive theoretical framework resting on a sophisticated analysis of causation and evaluation of the material from a political science perspective - one that would enable a critically informed appreciation of the nature and scale of the alleged failure and/or fiasco. Particularly marked in this literature is a tendency to objectivize the failure as a given, without attention to the constructed and politicized nature of the events in question.

It is, therefore, a welcome development that public policy and foreign policy scholars have recently begun working collaboratively to reignite the study of foreign policy failures. The fruits of this bridge building include a spate of fiascos workshops and conference panels that resulted in the 2016 Special Issue of the Journal of European Public Policy and a new edited collection on foreign policy mistakes (Kruck et al. 2017). These have aimed to move forward both sub-disciplines via reflection on the nature of policy failure (Bovens and ' $t$ Hart 2016) and, on the empirical side, by 'bringing public policy and foreign policy together' (Oppermann and Spencer 2016a). Examples include articles on the 2011 German abstention 
from a United Nations Security Council vote on intervention in Libya (Oppermann and Spencer 2016b) and the 2013 British parliamentary vote against military action in Syria (Gaskarth 2016). However, much of this literature still, variously, ignores, misunderstands or neglects policies involving secret intelligence. Bovens and 't Hart offer a cursory mention of intelligence when discussing typologies of failure, arguing that it falls in the 'tragedy' category in so far as 'accomplishments can often not be publicized, [and] may suffer from a similar lack of community and political appreciation' (2016: 658). This is fair, but overly simplistic in that it assumes programmatic success and does not account for failure. Likewise, Marsh and McConnell (2010b: 575) briefly discuss the contested success or failure of extraordinary rendition but consider neither secrecy nor how the operations came to light in the first place. Nonetheless, this new agenda provides a very welcome antidote to the benign neglect that previously characterized the relationship between scholars in the two fields. It was also a cue to our article, which adds covert action, with its inherent secrecy and controversy, into the mix.

Bringing covert action, as part of broader foreign policy activity, into dialogue with the public policy literature is valuable in at least three ways. First, scholars of International Relations and Foreign Policy Analysis have long been interested in the impact of various agentoriented factors (see Brummer 2016; Beasley 2016; Allison and Zelikow 1999) on decisions affecting international politics - and crucially how policy-makers learn lessons from these episodes (see Daddow 2011; Howlett 2012; Mumford 2015; Cormac et al. 2016). However, and this is especially the case for those studying covert action, scholars have not yet travelled very far down the road of conceptualizing and categorizing analytically all the different types of mistake/blunder/failure/fiasco (for an attempt using US cases see Walker and Malici 2011). Such categorization is necessary to provide fine-grained understandings of how failure is identified, labelled and constructed through various forms of political and discursive contestation. By extension, this will generate more nuanced lessons, which are especially 
required in an era when lesson-learning is the main way in which publics engage with foreign policy debates (see for instance The Report of the Iraq Inquiry 2016). Moreover, covert action, and the inherent secrecy therein, problematizes the lesson learning process of extracting visible information which can offer credible and generalizable lessons. The case study below is particularly relevant because it highlights how learning can occur from successful message management and fiasco containment, contributing novel information in a field dominated by learning from apparent failure.

Secondly, and linked to this, analysis of the domestic political settings within which foreign policy fiascos are constructed, and blame apportioned, casts much needed light on the interconnectedness between national and international politics. ${ }^{1}$ For foreign policy fiascos, no less than domestic fiascos, are only foreign policy fiascos when deemed to be so by domestic political audiences and commentators. Studying covert action contributes to this strand in so far as operations, when revealed, raise debates about democratic legitimacy, transparency, and oversight. In particular, it provides a vivid illustration of the ways in which external activity by a state can cause problems not only abroad ('over there' for 'others') but domestically too.

The third value of this research agenda is that it draws attention to the methodological challenges of conducting fiasco research. A lot but not all the current research in what is an encouragingly pluralist field is, broadly, interpretivist in nature (see Yanow 2000; SchwartzShea and Yanow 2012; Lynch 2014; Yanow and Schwartz-Shea 2014; Bevir and Daddow 2015). There is an argument to be made, however, that the distinctions between positivist and post-positivist research have been overdrawn; this is clearly evident in the fiascos literature. For example, positivist accounts do not deny an element of interpretation when evaluating public policies. Post-positivists stress the constructed nature of fiascos. However, they do not claim that anything can be said about a supposed public policy failure (echoing Oppermann 
and Spencer 2016a: 649-50) or that everything is discourse (Howarth et al. 2000: 3). Valid and reliable empirical evidence is the essential bedrock to both modes of inquiry.

Fiascos research is very well placed to tap into this meta-debate in the philosophy of social science, as well as those that occur within these traditions (Bevir 2002; Bevir and Rhodes 2016). Alan McConnell explains this point very well (2016:677), when he remarks that despite the formidable methodological challenges facing the fiasco analyst, this is not a challenge that should be shirked because they 'mirror classic methodological differences in the social sciences - whether the phenomenon being studied is a matter of "fact", interpretation or both'. Covert action, as discussed in the next section, starkly demonstrates the methodological conundrums facing all fiasco researchers. We develop a rigorous method of extracting and reporting the data which can travel to all types of alleged domestic and foreign policy fiasco. Importantly, our method enables us to explore alleged covert action failures without having to wait decades for the release of official documents, giving it real currency and immediacy. All in, therefore, our article advances significantly the cumulative research agenda across the board, methodologically, theoretically and empirically. We will now reflect in more detail on the nature of these challenges as seen from the perspective of the covert action fiasco analyst.

\section{Covert action: The challenge for fiasco construction}

Covert action is a state's attempts to interfere in the affairs of another in a plausibly deniable manner. It generally falls into one of four categories: political action, economic action, propaganda, and paramilitary action. By definition, covert action entails a controversial set of practices in international relations. When things go awry, the potential for fiasco narratives to emerge would seem to be very high. 
The fiasco - and broader policy evaluation - literature offers a useful framework for assessing the scope and limits of covert action as foreign policy choice. Mistakes and failures, although contested, are part of the daily life of any bureaucracy (McConnell 2016: 667). They are multifaceted, ranging in severity, cause and degree of politicization. They also come in many forms, including disasters, blunders, and catastrophes (see Gray 1998: 8; Moran 2001: 416-7; King and Crewe 2013: 4). Like success, failure is a subjective label 'applied by stakeholders and observers' (Bovens and 't Hart 2016: 654; see also McConnell 2016: 667684). Fiasco is a type of failure, and not all failures become fiascos. A policy fiasco is 'a negative event that is perceived by a socially and politically significant group of people in the community to be at least partially caused by avoidable and blameworthy failures of public policymakers' (Bovens and 't Hart 2016: 653-4). Generic failure, by contrast, does not necessarily contain an assumption that individual actions are at fault (McConnell 2016: 668). We therefore posit a crucial distinction between fiasco and failure: although both are subject to debate and contestation, fiascos are more politicized. Fiascos arise out of political or reputational failure as well as programmatic or decisional/implementation failure (Bovens and 't Hart 2016: 653-4, 658; Marsh and McConnell 2010: 571). Through discursive construction, they are visible, significant, public, and involve the attribution of blame.

Fiascos therefore 'share a common process' or are 'marked by the existence of particular patterns of beliefs about events' (Gray 1998: 8). The process, driven by the interpretative struggles therein, tends to involve four themes. Firstly, the perceived failing must be articulated by policy evaluation stakeholders to have been visible and immediate. Secondly, observers need to be able to identify causation. This process, as Michael Howlett (2012: 543) has pointed out, is heightened when failures are deemed to have been predictable and avoidable. Thirdly, observers have to be able to explain and interpret agents' behaviour: characterization and identification of the main players in the drama is important. According to Bovens et al 
(2006: 323), 'astute players of the evaluation game will therefore attempt to produce facts and images that suit their aims.' Such frame contestation leads to a fourth component featuring within the articulated discourse: blame allocation. The media offers a key arena in which this takes place, not least because it is by and through the media that fiasco frame contestations play out. By providing a 'pivotal forum for political sense-making,' it can be integral to explaining why some failures enter the limelight and escalate into fiascos (Bovens et al 1998: 48).

For the covert action analyst, these already challenging difficulties are magnified hugely. Ontologically, it is difficult to ascertain (usually shifting) policy goals against which to measure outcomes, and if we do not know what the goal was, how can we say that it failed, or indeed succeeded (McConnell 2016: 669)? Owing to the inherent secrecy of covert operations, it is very tricky to identify and label a covert operation a failure in the first place, let alone politicize it, allocate blame and construct a resonant fiasco narrative. Why? Because secrecy restricts the information flows required to emplot a credible story about what occurred and therefore limits the capacity of outside commentators to seek out the causes of any alleged failure. There is the further complicating issue of short-term success versus long-term failure, a feature so prevalent in covert action that it even has its own term: 'blowback'. CIA aid to the Mujahedeen in Afghanistan during the 1980s is perhaps the most widely-cited example, in so far as it created a power vacuum inside Afghanistan which Al Qaeda could later exploit (Prados 2009: 293). Problems assessing impact and agency also impede policy evaluation. The nature of covert action, which often involves deniably supporting existing forces, renders it difficult to judge the effect of a particular policy, even if we know the original goal. For example, historians still debate the relative influence of CIA activity versus pre-existing internal agency in such cases as the 1953 Iranian coup, unrest in Congo in the early 1960s, and the 1973 Chilean coup (see Bayandor 2010; Daugherty 2009: 7; Haslam 2005; Devine 2014). 
Even when an operation - which stakeholders accuse of having failed - does come to light, secrecy and deliberate obfuscation hide details which are essential to the construction of fiasco narratives. Moreover, the passage of time between failure and public knowledge - and the slow and sporadic dripping of revelations by historians working on archival records - has long prevented the necessary politicization for covert action failure to become fiasco. By the time a story of failure finally breaks, those in office may have died, events lack a temporal immediacy, and there is little media or public appetite to rake over 'old ground'. AngloAmerican attempts to overthrow the Albanian government from 1949, for example, are now seen to have badly failed; yet the operation lacked visibility and spatial immediacy, rendering it difficult for anyone outside of a small circle to construct failure let alone fiasco. And, over 60 years on, historians are still debating the chronology of events and where to assign blame (see Jeffery 2011: 715; MacIntyre 2014: 120).

Even confronted with these obstacles, covert action fiascos have been said to have occurred. We suggest that there is a discernible pattern in the narrative construction of each. In line with public policy literature discussed above, the process includes, firstly, a perceived visible, immediate, and consequential failure, with sufficient momentum to sustain a fiasco narrative. Second, there is a transfer of information, often through an accountability forum such as the media, which challenges government monopoly on information, and out of which stakeholders are keen to make political capital. Third, there is an attempt to identify the source of the alleged failure, usually spanning one or more levels of analysis: individual decisionmakers, a wing of the bureaucracy, or perhaps the strategic foreign policy outlook of the government in toto. The identification of the source(s) or origin(s) of the perceived negative outcome a vital function of the fiasco narrative that includes: causation, (un)avoidability, uncertainty about goals and so on. Each ingredient is weighed differently by participants arguing about whether and how far the operation was a fiasco. The core factor in each of the 
above is access to information: without details of the operation, neither failure nor fiasco can be constructed. This is one of the major findings from our case study data, as detailed below.

To put some empirical flesh on these patterns, we can look to the 1961 Bay of Pigs fiasco, when the CIA supported Cuban exiles in an attempted revolution, or the 1997 Khaled Mashal fiasco, when Israel's secret service, Mossad, botched the assassination of a Hamas leader (Kahana 2007: 65). Both were visible and immediate: the sponsoring state was quickly identified and the operation sparked much public discussion. Both were successfully articulated as being sufficiently consequential in terms of impact on policy and prestige to warrant the resources necessary to detailed investigative journalism (on America see Wyden 1979: 295, 305; Johnson 1964: 220; Haefele 2001: 77-8); on Israel see Cowell: 1997).

Both cases also involved a transfer of information to the accountability forum of the press, which challenged the government's monopoly over information and allowed stakeholders to politicize failure and construct the fiasco. Regarding the Bay of Pigs, the press already had the details, via a series of leaks, before the operation happened, but had been persuaded by policy-makers not to publish for the sake of national security. Following the perceived failure, senior administration officials, including the President and the director of the CIA, gave numerous unattributable briefings, which involved much finger pointing and blame avoidance (Barrett 2016: 6-23). Similarly, Mossad briefed reporters with off-the-record details, whilst the Israeli Prime Minister attempted to make intelligence a scapegoat (Pateman, 2003: 154). This permitted characterization and the identification of agency, both of which are integral to fiasco emplotment but, which, usually remain obscured regarding covert action.

The US's failed Iranian hostage rescue in 1980 and the 1986 Iran-Contra affair further illustrate some of the ingredients essential to a successful fiasco construction. ${ }^{2}$ In both instances, the government lost its monopoly over information, opening the way for the emergence of credible fiasco narratives via politicization of the issue, public discussions about magnitude 
and consequence, and the allocation of blame (on Iran-Contra see Brody and Shapiro 1989: 353-369; on the rescue attempt see Smith 1985: 117-123; Holloway et al 1980). In all the cases explored above, the transfer of information was key. When the transfer took place, the government suddenly found itself at a disadvantage regarding covert action compared to overt action: issues of secrecy and operational security, asset protection and potential diplomatic fallout can constrain the government from constructing a compelling counter-narrative. The case study data presented in the next section shows vividly how and why these are the essential ingredients in a successful fiasco construction.

\section{Information asymmetry and the battle of narratives over Libya ${ }^{3}$}

Fiasco authors - journalists, historians and public policy analysts - tell fiasco stories in narrative form, through which they give the events meaning for readers (White 1992: 4; Gunn 2006: 37-38; Klotz and Lynch 2007: 45-51). Consensus around certain core 'facts of the matter' results in the repetition of keywords and phrases that offer themselves up as empirical patterns identifiable in the data (Klotz and Lynch 2007: 53-54). These patterns delimit a discourse 'field' that helps structure - but does not determine - what can and cannot be said on a given issue (see Howarth et al. 2000: 15; Wetherell et al. 2009: 7-8). The more basic facts that can be established, and the greater the certainty about those facts, the more likely it is that a particular narrative interpretation will establish credibility amidst the 'noise' of counter-narratives and rival emplotments.

The pertinent feature of fiasco narratives is that they are constructed very clearly as morality plays. This should not be a surprise because as White remarks (1975: 14): it 'seems possible to conclude that every historical narrative has as its latent or manifest purpose the desire to moralize the events of which it treats' (see also Daddow 2006). Fiasco narratives thus 
contain two interconnected features that make them fertile sources of evidence about the politics of fiasco construction (drawing on Oppermann and Spencer 2016b: 691). First, they emplot the reasons why a failure occurred. Second, they pinpoint who or what was to blame for the failure and debate what could have been done differently to avoid the incidents or decisions that led to the (usually negative) outcome.

The method selected for the analysis of the coverage of Hague's Libyan venture was, therefore, a close study of media narratives, unpacked using discourse analysis of the relevant news reporting and opinion pieces. The research questions that guided our extraction of the data were all geared to investigating the setting, characterization and emplotment of the media reporting: (i) who were the main actors in the Libyan episode, where were they operating, and what were they doing? (ii) what was the magnitude of the failure - if any - and who was to blame for any alleged failings? (iii) what were the resistances to the fiasco narratives and how successful were they? We studied the coverage from the day the story broke on 6 March 2011 and tracked how it unfolded for the next ten days. Searches on Lexis delivered nearly 150 newspaper articles, and these were accompanied by a study of writing in the Financial Times which did not feature on the database. We did not study the broadcast media on this occasion for reasons of space, but it would be interesting to assess how far the same stories fed television and radio coverage of Hague's Libyan venture.

When the story of the British detainees in Libya broke on 6 March 2011 it was evident that, lacking an official account of what had happened - via a press conference, interview, or other political statement - journalists had a desperately difficult job establishing what had transpired, especially who was involved. Phase One of the media coverage was thus driven by factual uncertainty regarding both cast (who was involved in the story?) and the equipment they had on them at the time of capture. The Sunday Times, which broke the story, put the figure at 'soldiers - up to eight men' captured escorting a 'junior diplomat' through rebel-held 
territory in the east of the country (Jaber 2011). Others followed suit but there was little consensus about the numbers involved or their identities with speculation covering soldiers, SAS, diplomats, and MI6 agents. There was only marginally more agreement on the equipment the seized men were carrying, and the reporting again spoke to the James Bond-style nature of the mission. Sensationalized speculation stretched to fake passports, maps, communications equipment, and weapons.

After a couple of days (some overlap aside) the information-gathering phase gave way to Phase Two: blame attribution. Attempts at fiasco construction were built on shaky empirical foundations because characterization had been so weak in Phase One. There was, however, early and widespread agreement that something had gone wrong with Hague's Libyan operation, the failure of which was deemed visible and controversial. A sense of government 'cover up' was also in the air. In line with the aforementioned ingredients identified for a successful fiasco construction, someone had to be to blame. Coding for the adjectives used to describe the mission revealed around 20 negative descriptors of varying degrees of strength, including failure, bungle, and, indeed, fiasco. Managing the consequences of this heavily negative verdict became the government's main task over the next few days. The success of its resistance narratives and message management would determine the future of Hague himself and the credibility of the Cameron government's Libyan and wider foreign policy.

The consequences of any perceived failure were most grave for Hague himself, with the Prime Minister and government as a whole also implicated. Only a tiny portion of the flak was taken by then head of MI6, John Sawers (Sherwood 2011). This was very much a story centring on the 'Westminster bubble'. Three facets of the media coverage are noteworthy in this respect: the information vacuum; the sense that the British lacked control over what information was coming out of Libya; and the debate about Hague's role and responsibility. 
First, central government personnel, constrained by secrecy and operational security, initially came forward with very limited information. One national and some regional newspapers picked up on comments from Defence Secretary Liam Fox. He defended the operation on the grounds that it was intended to 'build a picture' of what was going on in Libya 'so we are able to get a clearer idea of what we are able to do in terms of helping the people of Libya' (Chulov 2011a; The Western Mail 2011; Coventry Evening Telegraph 2011; Daily Post 2011). The Independent on 6 March reported that International Development Secretary Andrew Mitchell had taken a similar line in a radio interview. There was no official comment, again because of the classified nature of the operation, from the Foreign Office or Ministry of Defence (Tapsfield 2011). However, these unofficial remarks indicate that government ministers were spinning the operation as intelligence-gathering (legitimate, tactical and routine) rather than a more sensitive event-shaping activity, clearly aiming to decrease the salience of the matter. The Prime Minister's Office was approached by journalists but also declined to reveal details, merely adding that Hague had approved the operation 'in the normal way' (Wintour 2011). The government's line was that this was 'business as usual'.

Second, the lack of official information on the British side left the way clear for journalists to fill their copy with information gleaned from the Libyan side. Crucially, this emerged very early, adding to the sense that something was amiss. Top billing was given to a leaked telephone conversation between Richard Northern, the UK Ambassador to Libya, and a Libyan rebel leader, which took place in the immediate aftermath of the incident. In the short exchange, Northern apologized for the 'misunderstanding' and the leader chastised the 'mistake' of sending the mission team in by helicopter at night (for example Chulov 2011a; Watt 2011b; Judd et al 2011; The Journal 2011; Wheeler and Newton Dunn 2011; Cecil 2011b; Dawar 2011; Radnedge 2011c). The interception and broadcast of their conversation was portrayed as another element of farce (Evening Times 2011) by playing into the hands of Libyan 
leader Muammar Gaddafi. Covert action can thus work both ways for a government, when an operation is deemed to have gone wrong. On the one hand, information asymmetry can work in a government's favour to stymy potential fiasco construction. On the other hand, it can also constrain a government's ability to construct a compelling counter-narrative, allowing journalists to speculate and build new foundations on which to construct fiasco narratives.

The third noteworthy pattern in the media coverage was the attribution of blame squarely on the shoulders of the Foreign Secretary, as the originator of the operation. Consistent with public policy fiascos, the press (from across the political spectrum) highlighted the avoidable nature of the failure by emphasizing poor planning, judgement, and scrutiny (see for example Wintour 2011; Hughes 2011b; Coughlin 2011b). As with previous covert actions which surfaced as perceived failures, Libya had created political space between the government's intentions and the outcome, which was ruthlessly exploited by Hague's opponents. Political leaders need to make meaning and to 'fill this space with their own interpretation' of the narrative (McConnell et al 2008: 602). Hague was trapped between the need for secrecy and the press's traditional support for 'brave' and 'heroic' Special Forces at the expense of bumbling politicians. To Hague's credit, he made a statement to the House of Commons and answered questions on the afternoon of 7 March about the Libya incident. Although secrecy impeded Hague from giving full details, he afforded himself enough latitude to ensure that this transfer of information was carefully framed to maintain government dominance of the narrative. In taking this step, Hague entered into a 'frame contest', which arises in the aftermath of crises and which affects beliefs and the relative importance individuals attach to those beliefs (Boin et al 2009: 82; Gershkoff and Kushner 2005: 526).

The Foreign Secretary stated: 'I authorised the dispatch of a small British diplomatic team to eastern Libya in uncertain circumstances, which we judged required protection, to build on these initial contacts and to assess the scope for closer diplomatic dialogue' (Hague 2011: 
cm643). Hague unsurprisingly offered no admission that the diplomatic team consisted of MI6 and SAS personnel. After all, political actors are risk-averse and will not offer extra detail unless it suits them, or they are forced to (Edwards III and Wood 1999: 342). Hague continued by explaining that the team 'was withdrawn yesterday after a serious misunderstanding about its role, leading to its temporary detention.' These deliberately bland statements normalized the incident by framing it as part of everyday, rational and legitimate Foreign Office activity. He even attempted to sell the operation as having been partially successful: 'this situation was resolved and [the team] was able to meet council president, Mr Abdul-Jalil. [...] We intend to send further diplomats to eastern Libya in due course' (Hague 2011: cm643).

Contrary to Hague's anodyne rendering of the operation, opposition politicians sought to frame the events somewhat differently. The public policy literature argues that 'fiascos and prominent failures attract those interests that seek to capitalize on those failures' (McConnell et al 2008: 601). Despite the national security implications, observers clearly sought to make political capital out of the Libya operation. Douglas Alexander, Labour's Shadow Foreign Secretary, accused Hague of mishandling the affair: 'does the Foreign Secretary accept that if some new neighbours moved into his street, the British public would be entitled to wonder whether he would introduce himself by ringing the doorbell, or instead choose to climb over the fence in the middle of the night?' (Alexander 2011: cm646). A good joke always plays well with journalists and political sketch-writers, and this was widely reported. Journalists were encouraged in their attacks by accusations of 'bungling' and incompetence not only from opposition ministers, but some of Hague's fellow Conservatives and members of the Coalition government. Former Liberal Democrat leader Menzies Campbell was widely reported to be behind open speculation about whether Hague still had the stomach for what he described as a 'very, very hard...very, very demanding job' (see Bentley 2011; White 2011; Sun 2011; Sunday Business Post 2011; Heaven 2011). In the debate he asked: 'Is it not clear that this 
mission was ill conceived, poorly planned and embarrassingly executed?' (Campbell 2011: cm649). Events were framed firstly as failure and secondly as avoidable, all overlaid with an element of farce. Hague, however, defended himself by taking 'full ministerial responsibility' (supporting the Downing Street line) and drew on Northern's defence that this was a 'misunderstanding' but nothing more sinister.

The following days saw further attempts by Hague's opponents to bolster the resonance of the fiasco narrative and undermine the Foreign Secretary. In this endeavor, parliamentary routine was on their side. Just two days after Hague's statement and initial interrogation, Prime Minister's Questions on 9 March provided a high-profile opportunity for the opposition leader Ed Miliband to land some telling punches on what he called the 'fiasco' of the government's Libyan policy (Kirkup 2011). There was, he said, 'a question of competence at the heart of this government' (Churcher 2011). However, Cameron stood by Hague, calling him an 'excellent' minister and taking 'full responsibility for everything that my government does' (Kirkup 2011; Leicester Mercury 2011a; Metro 2011). Hague, it seemed, was not to be isolated or picked off, despite the fevered speculation (for instance Richards 2011). To help the embattled Foreign Secretary, Downing Street also briefed journalists that Hague had Cameron's full support, along with the backing of fellow Cabinet ministers. There was, said the Prime Minister's official spokesman, no plan for a Cabinet reshuffle 'any time soon' (Bentley 2011). These briefings emphasized the supposedly harmonious working relationship between Cameron and the three foreign affairs-related ministers, Hague, Fox and Mitchell (Kirkup 2011). Hague emerged from the episode bloodied and bowed, but was not beaten into a resignation.

As the fallout continued in the media over the ensuing days the Daily Telegraph was a vocal but almost lone supporter of the Foreign Secretary. An article by Peter Oborne on 11 March claimed Hague was the victim of a 'smear campaign' by rival politicians involved in a 'battle for power'. Oborne further charged that SAS operational planning was to blame, and 
that it had been Hague's constitutional duty to take responsibility for errors caused by the bungling of others. Oborne also questioned the idea that this was part of a series of failures in the government's Libyan policy, especially regarding the evacuation of British nationals at the outbreak of hostilities (all in Oborne 2011). On 13 March Hague himself gave an interview to what was clearly his favourite newspaper, the Conservative-supporting Sunday Telegraph, in which he tried to end speculation about his future and Cameron's support for him (see Bentley 2011). This was extensively covered as Hague saying 'I've still got my mojo' (a direct response to Liberal Democrat criticisms) (Sun 2011) and that he would continue in office 'for an extensive period of time' (Heaven 2011). Hague's biographer Jo-Anne Nadler added her view that Hague would not walk away from Cabinet and that he was only struggling in the job because the Cameron government was struggling to articulate its ambitions for British foreign policy (The Northern Echo 2011).

Our analysis of media narratives reveals that, consistent with fiasco construction processes observed in the extant literature, socially and politically significant groups, having identified failure, attempted to highlight avoidable mistakes. Some in The Telegraph, for example, argued that 'it is not the SAS that should hang its head in shame over this fiasco: it is the idiots who authorized it in the first place' (Coughlin 2011a). Similarly, The Daily Mirror quoted an ex-SAS member who accused the mission of being 'badly planned and underresourced' (Hughes 2011a) and, by implication, avoidable. This is not necessarily fair, as it would have been the Director of Special Forces who advised Hague on feasibility. Yet the narrative ties in with a 'lions led by donkeys' frame, emphasizing the romance and mythologies surrounding Special Forces and MI6, who are generally held in higher regard than supposedly amateurish, blundering politicians (for a typically hagiographic example shortly after the failure see Harding 2011). 
Libya, however, did not become a full-blown fiasco - in the technical sense - seemingly for three reasons. First, journalists interpreted the operation as a visible and immediate failure, but did not interpret it as sufficiently consequential to dig for inflammatory details over a prolonged period. The narrative that came to dominate was that the Libyan venture lacked the costly and very visible consequences associated with decisions as the invasion of Iraq in 2003 (see Ricks 2006; Bovens and 't Hart 2016: 655 and 660-661). Had a covert operation turned out similarly in Iraq as opposed to Libya, one suspects the fallout would have been much more severe because a prior narrative of policy failure would already have been in place. Unlike Iraq, the Libyan venture was not deemed serious enough - and the overall strategy not contentious enough - to warrant an inquiry, which might have reignited discussion and led to post-hoc fiasco construction. Hague's narrative in fact came to be accepted as the official line, an important indicator of success in this kind of narrative contestation (Klotz and Lynch 2007: $55)$.

For example, the following year's Intelligence and Security Committee annual report limited formal criticism to a paragraph which blamed the botched operation on time pressures and a lack of planning (Intelligence and Security Committee 2012: 19). Likewise, the Cabinet Office's lesson learning retrospective reduced the incident to a 'serious misunderstanding' which was quickly resolved. In doing so it almost repeated Hague's words verbatim (National Security Adviser 2011: 9-10). By the time Hague stepped down as Foreign Secretary, Britain's Libya policy was hotly contested, but his March 2011 venture had seemingly been forgotten, even by close observers. Looking back on his record in politics, Hague was able to claim that Libya had not caused any divisions between the senior Conservative members of the Coalition government. Furthermore, he said: 'I don't think I made any calamitous mistake on any issue' (Economist 2015). He would have been hard pushed to substantiate these claims had the Libyan episode been worked up into a credible fiasco narrative. 
Second, the short-lived attempt by journalists to create a fiasco narrative is in part explained by the structuring effects of shifting media agendas. Soon after the story broke, a large earthquake and tsunami struck Japan, killing around 20,000 people and causing a nuclear accident. The next eight weeks also included a Royal Wedding in the UK and the death of Osama bin Laden. Media attention can only last so long and the agenda was soon overtaken by other - equally dramatic - events, ones with obvious global political consequences that made for better news stories. It would require a separate article to theorize the association between commercial media decisions and fiasco construction. However, the evidence from our case study suggests that whilst the saliency of Hague's Libyan venture was very high for a brief period, more sense of intrigue or consequence - not to mention a whiff of scandal, cover-up or other wrongdoing - was required for stakeholders to continue to invest resources in chasing down elusive facts about wat had transpired far away in the Libyan desert outside Benghazi.

With or without the agglomeration of more newsworthy stories, this fiasco construction might not have taken off for the third reason: the requirements of operational secrecy hindered the media's ability to establish the facts of the matter. The case did involve the transfer of information via parliament, which challenged the executive's usual monopoly over such matters. However, official information was limited and framed blandly, thus taking the sting out of the fiasco narratives. Observers lacked even basic data on the operation to be able to explain agents' behaviour and to apportion blame. The Guardian, for instance, ended up turning its attention to the 'arrogant' government silence (Norton-Taylor 2011). Moreover, the operation came amidst a fast-moving civil war, part of the Arab Spring, which was ushering in a period of intense global uncertainty reminiscent of the collapse of Communism in Eastern Europe. At the grand strategic level, the government had secured bipartisan support for its actions in Libya, including the need to protect civilians in the civil war. Negotiations were already underway regarding no-fly zones, and just two weeks later MPs overwhelmingly voted 
in favour of military action to protect civilians. The press supported these key decisions. This strategic consensus clearly sapped the willingness even of Hague's many opponents to continue to try to land political punches on him.

\section{Conclusions}

Our investigation of Hague's Libyan venture highlights the multiple ingredients required for the successful construction of a fiasco narrative: politics, power, intent and contingency all play key parts. Our case study supports a well-known finding in the field of Foreign Policy Analysis (Houghton, 2007: 25) that information is power and the main currency of foreign policy narratives. The foreign policy marketplace, as Baum and Potter (2008: 42) put it, 'is driven primarily by the distribution of the key market commodity' - information - among the policymakers, media and public opinion. Our contribution allows us to add to this argument by showing precisely why it is that the emergence of an accountability forum within which information can circulate is crucial, yet also one of the hardest things to achieve for interested stakeholders. Information, especially in covert action, overwhelmingly favours the policymakers.

Our first conclusion is, therefore, that lack of access to information is the prime reason why a perceived covert action failure, and a national security failure more broadly, will not easily result in the successful construction of a fiasco narrative. As the Libya case study reveals starkly, it is very difficult to construct covert action fiascos. Secrecy, government monopoly over information, and the problematic ontologies of identifying policy goals impede even those operations deemed to have failed from becoming talked about as fiascos. This creates a fascinating paradox considered in this article: public policy failures are more likely to become emplotted as fiascos despite being less controversial and less risky, simply because they are 
more visible and stakeholders have more information ready to hand. Even short-lived, failed fiasco constructions such as that explored in this article offer vital information on the subjective nature of fiasco narratives.

Our second conclusion is that the role of secrecy is determinative when evaluating covert action and yet is only loosely acknowledged and accounted for in existing attempts at mid-range theoretical explanations of policy failure. This article has not sought to develop its own theory of secrecy, but has introduced the idea of secrecy into scholarly debates as a point for discussion moving forward. Our article has revealed that the discourse surrounding covert action failures exhibit different emphases and some special characteristics compared to 'overt' or routine foreign policy activity. However, we are dealing with differences of magnitude not of kind, hence the urgent need for attention to the idea of secrecy in the fiascos literature. From our evidence, we suggest that secrecy can be a government's best defence against fiasco construction. Yet once commentators latch onto covert action mistakes, elites are suddenly placed in a difficult position. They cannot fully defend themselves without undermining official secrecy and/or potentially damaging delicate diplomatic relations with other states, or criticizing Special Forces and the intelligence services, which have long been romanticized in the public imagination. We argue, therefore, that attempts at fiasco construction offer insight into the power relations at play in attempts to construct and control a narrative. The study of covert action fiasco narratives is especially well placed to deliver rare insights into the most secret of policy spaces.

Our third conclusion is that secrecy seriously complicates lesson learning. Many studies, in asserting their policy relevance, argue that opening policy-making to a genuine contest of ideas is the best way to prevent fiasco - and failure more broadly (Bovens and 't Hart 2016: 662). Yet covert action is the one area of policy least likely to be subject to democratic debate, even in an era of increasing official oversight and growing public interest in foreign policy. At 
the same time, blame games and political point scoring associated with fiascos, exaggerated when a controversial covert action is under the microscope, can obscure relevant lessons altogether (Gray 1998).

Our fourth conclusion is that, from the study of covert action successes and failures, policy-makers can learn vital things about the construction of blame avoidance under the rubric of 'message management'. This gives lesson learning a vital new twist from that generally on offer in the literature, because policy-makers learn as much from blame avoidance, frame contestation, and the political construction of success and failure as they do from rational evidence-based prescriptions. It is all too easy for policy-makers to assume that covert action will stay secret; they therefore tend to underestimate the political implications of disclosure. Governments communicate all sorts of messages about policies daily, but there seems little energy devoted to reflecting on the whys, wherefores, pros and cons of different types of message management under routine and crisis conditions. Studying the construction of covert action fiascos lays bare these practical challenges to policy-makers by showing the obvious potential for fiascos scholarship to impact on policy. This is no straightforward task and will require further bridges to be built between the worlds of policy and academe. Cross-fertilization of research and experiences between academics and foreign policy-makers, in line with the revivified research agenda of which this article is a part, will perhaps encourage governments to better consider the political ramifications of disclosure before sanctioning covert actions which, in an increasingly digital world, are ever less likely to remain secret.

Supplemental data for this article can be accessed at [link to source - publisher will add doi at proof]

\section{Notes on Contributors}


Rory Cormac is an Associate Professor of International Relations at the University of Nottingham, UK.

Oliver Daddow is an Assistant Professor in British Politics and Security at the University of Nottingham, UK.

Rory.Cormac@nottingham.ac.uk; Oliver.Daddow@nottingham.ac.uk

\section{Acknowledgements}

The authors would like to thank Jon Moran, Kai Oppermann, Kelly Smith, as well as the four anonymous journal reviewers, whose comments greatly helped sharpen up the final piece.

\section{Notes}

\footnotetext{
${ }^{1}$ We are grateful to one of the journal reviewers for drawing our attention to the domestic/international point.

${ }^{2}$ The hostage rescue was a secret military operation not a covert action, and it is debatable whether the Iran-Contra affair, often labelled a scandal, constitutes a fiasco (the latter hinges on interpretations of programmatic success). The differences between them lie beyond the scope of this article, but are referred to here as they are relevant to the core theme of secrecy.

${ }^{3}$ The source data and references are found in the online appendix.
}

\section{References}


Aldrich, R. (2001) The Hidden Hand: Britain, America and Cold War Secret Intelligence, London: John Murray.

Alexander, D. (2011) 'Libya and the Middle East', Hansard, cm:646, 7 March 2011, available at http://www.publications.parliament.uk/pa/cm201011/cmhansrd/cm110307/debtext/1103070001.htm\#11030711000002 (accessed 27 June 2016).

Allison, G. and Zelikow, P. (1999) Essence of Decision: Explaining the Cuban Missile Crisis, 2nd edn, London: Longman.

Barrett, D. (2016) 'If an Off-the-Record Briefing about Covert Action Remains Secret, Did It Ever Happen? JFK, Bay of Pigs, and a Secret Press Briefing', Paper presented at the ISA annual convention, Atlanta GA, 15 March 2016.

Baum, M. and Potter, P. (2008) 'The Relationship Between Mass Media, Public Opinion and Foreign Policy: Towards a Theoretical Synthesis', Annual Review of Political Science, 11: $39-65$.

Beasley, R. (2016) 'Dissonance and Decision-making Mistakes in the Age of Risk', Journal of European Public Policy, 23(5): 771-787.

Bayandor, D. (2010) Iran and the CIA: The Fall of Mosaddeq Revisited, Basingstoke: Palgrave.

Bevir, M. (2002) The Logic of the History of Ideas, Cambridge: Cambridge University Press. 
Bevir, M. and Daddow, O. (2015) 'Interpreting Foreign Policy: National, Comparative, and Regional Studies', International Relations, 29(3): 273-287.

Bevir, M. and Rhodes, R.A.W. (2016) Rethinking Governance: Ruling, Rationalities and Resistance, London: Routledge.

Boin, A. et al, (2009), 'Crisis Exploitation: Political and Policy Impacts of Framing Contests', Journal of European Public Policy, 16(1): 81-106.

Bovens, M. and 't Hart, P. (2016) 'Revisiting the Study of Policy Failures', Journal of European Public Policy, 23(5): 653-666.

Bovens, M. and 't Hart, P. (1996) Understanding Policy Fiascoes, London: Transaction.

Bovens, M. et al (2006) 'The Politics of Policy Evaluation', in Michael Moran et al (eds.) The Oxford Handbook of Public Policy, Oxford: Oxford University Press.

Bovens, M. et al (1998) 'The Mass Media and Policy Disasters: The IRT Disaster and the Crisis in Crime Fighting in the Netherlands', in Pat Gray and Paul 't Hart (eds.), Public Policy Disasters in Western Europe, Abingdon: Routledge.

Brody, R. and Shapiro, C., (1989) 'Policy Failure and Public Support: The Iran-Contra Affair and Public Assessment of President Reagan', Political Behavior, 11/4, 353-369. 
Brummer, K. (2016) '”Fiasco Prime Ministers": Leaders’ Beliefs and Personality Traits as Possible Causes for Policy Fiascos', Journal of European Public Policy, 23(5): 702-717.

Byrne, M. (2014) Iran-Contra: Reagan's Scandal and the Unchecked Abuse of Presidential Power, Kansas US: University Press of Kansas.

Campbell, M. (2011) 'Libya and the Middle East', Hansard, cm649, 7 March 2011, available at http://www.publications.parliament.uk/pa/cm201011/cmhansrd/cm110307/debtext/1103070001.htm\#11030711000002 (accessed 27 June 2016).

Cohen, H. et al, (2015) 'Who Lost Congo? The Consequences of Covert Action', Foreign Affairs, January/February, available at http://www.foreignaffairs.com/articles/142485/hermanj-cohen\%E2\%80\%A8-charles-g-cogan-stephen-r-weissman/who-lost-congo (accessed 27 June 2016).

Cormac, R., Goodman, M.S. and Holman, T. (2016) 'A Modern-day Requirement for Coordinated Covert Action: Lessons from Britain's Intelligence History', The RUSI Journal, 161(2): 14-21.

Cowell, A. (1997) 'The Daring Attack that Blew up in Israel's Face', The New York Times, 15 October, available at http://www.nytimes.com/1997/10/15/world/the-daring-attack-that-blewup-in-israel-s-face.html?pagewanted=1 (accessed 27 June 2016). 
Daddow, O. (2006) 'Postmodernism and the Politics of Historiography', in Alexander Lyon Macfie (ed.) The Philosophy of History: Talks Given at the Institute of Historical Research, London, 2000-2006, Basingstoke: Palgrave Macmillan, pp. 155-72.

Daddow, O. (2011) New Labour and the European Union: Blair and Brown's Logic of History, Manchester: Manchester University Press.

Daugherty, W. (2009) Executive Secrets: Covert Action and the Presidency, Kentucky: University Press of Kentucky.

Devine, J. (2014) 'What Really Happened in Chile', Foreign Affairs, July/August, available at http://www.foreignaffairs.com/articles/141453/jack-devine/what-really-happened-in-chile (accessed 27 June 2016).

Economist (2015) 'An Interview with William Hague', 11 April, available at http://www.economist.com/news/britain/21648248-britains-former-foreign-secretary-reflectshis-career-conservative-party-and-britains-foreign (accessed 18 October 2016).

Edwards III, G. and Wood, B.D. (1999) 'Who Influences Whom? The President, Congress, and the Public', American Review of Political Science, 93(2): 327-44.

Gaskarth, J., 'The Fiasco of the 2013 Syria Votes: Decline and Denial in British Foreign Policy', Journal of European Public Policy, 23(5): 718-734. 
Gershkoff, A. and Kushner, S. (2005) 'Shaping Public Opinion: The 9/11-Iraq Connection in the Bush Administration's Rhetoric', Perspectives on Politics, 3: 525-38.

Gray, P. (1998) 'Policy Disasters in Europe: An Introduction', in Pat Gray and Paul 't Hart (eds.), Public Policy Disasters in Western Europe, Abingdon: Routledge.

Gunn, S. (2006) History and Cultural Theory, London: Pearson Education.

Harding, T. (2011) 'SAS: The Chosen Few Who Are a Force Like No Other', The Telegraph, 25 April, http://www.telegraph.co.uk/news/uknews/defence/8472610/SAS-the-chosen-fewwho-are-a-force-like-no-other.html

Haslam, J. (2005) The Nixon Administration and the Death of Allende's Chile: A Case of Assisted Suicide, New York, Verso.

Haefele, M. (2001) 'J.F.K. USA and World Public Opinion', Diplomatic History, 25(1): 63-84.

Holloway, J., et al, (1980), The Holloway report into Operation Eagle Claw, available at < https://www2.gwu.edu/ nsarchiv/NSAEBB/NSAEBB63/doc8.pdf>.

Houghton, D. (2007) 'Reinvigorating the Study of Foreign Policy Decision Making: Towards a Constructivist Approach', Foreign Policy Analysis, 3: 24-45. 
Howarth, D., Norval, A.J. and Stavrakakis, Y. (eds) (2000) Discourse Theory and Political Analysis: Identities, Hegemonies and Social Change, Manchester: Manchester University Press.

Howlett, M. (2012) 'The Lessons of Failure: Learning and Blame Avoidance in Public PolicyMaking', International Political Science Review, 33(5): 539-55.

Jeffery, K. (2011) MI6: The History of the Secret Intelligence Service, 1909-1949, London: Bloomsbury.

Johnson, H. (1964) The Bay of Pigs: The Leaders' Story of Brigade 2506, New York: W. W. Norton and Co.

Kahana, E. (2007) 'The Israeli Experience', in L. Johnson (ed.) Strategic Intelligence Volume 3: Covert Action: Behind the Veils of Secret Foreign Policy, Westport: Praeger, pp.61-82.

King, A., and Crewe, I. (2013) The Blunders of Our Governments, London: Oneworld.

Klotz, A. and Lynch, C. (2007) Strategies for Research in Constructivist International Relations, London: M.E. Sharpe.

Kruck, A., Oppermann, K. and Spencer, A. (eds) (2017) Making Mistakes: Political Blunders and Policy Failures in International Relations, Basingstoke: Palgrave Macmillan.

Lynch, C. (2014) Interpreting International Politics, London: Routledge. 
Marsh, D. and McConnell, A. (2010) 'Towards a Framework for Establishing Policy Success', Public Administration, 88(2), 564-83.

McConnell, A. et al (2008) 'Policy Fiascos, Blame Management and AWB Limited: The Howard Government's Escape from the Iraq Wheat Scandal', Australian Journal of Political Science, 43(4): 599-616.

McConnell, A. (2010a) Understanding Policy Success: Rethinking Public Policy, Basingstoke: Palgrave.

McConnell, A. (2010b) 'Policy Success, Failure, and the Grey Areas In-between', Journal of Public Policy, 30(3), 345-62.

McConnell, A. (2016), 'A Public Policy Approach to Understanding the Nature and Causes of Foreign Policy Failure', Journal of European Public Policy, 23(5): 667-684.

McIntyre, B. (2014) A Spy Among Friends: Kim Philby and the Great Betrayal, London: Bloomsbury)

Moran, M. (2001) 'Not Steering but Drowning: Policy Catastrophe and the Regulatory State', The Political Quarterly, 72(4): 414-27.

Mumford, A. (2015) 'Parallels, Prescience and the Past: Analogical Reasoning and Contemporary International Politics', International Politics, 52(1): 1-19. 
National Security Adviser, (2011), 'Libya Crisis: National Security Adviser's Review of Central Co-Ordination and Lessons Learned.', London: Crown, available at https://www.gov.uk/government/uploads/system/uploads/attachment_data/file/193145/Lesso ns-Learned-30-Nov.pdf (accessed 4 October 2016).

Oppermann, K. and Spencer, A., (2016a) 'Studying Fiascos: Bringing Public and Foreign Policy Together', Journal of European Public Policy, 23(5): 643-652.

Oppermann, K. and Spencer, A., (2016b) 'Telling Stories of Failure: Narrative Constructions of Foreign Policy Fiascos', Journal of European Public Policy, 23(5): 685-701.

Pateman, R. (2003) Residual Uncertainty: Trying to Avoid Intelligence and Policy Mistakes in the Modern World, Janham, MD: University Press of America.

Prados, J. (2009) 'The Future of Covert Action', in L. Johnson (ed.) Handbook of Intelligence Studies, Abingdon: Routledge, pp.289-298.

Rasenberger, J. (2012) The Brilliant Disaster: JFK, Castro, and America's Doomed Invasion of Cuba's Bay of Pigs, New York City, NY: Scribner.

Ricks, T.E. (2006) Fiasco: The American Military Adventure in Iraq, London: Allen Lane.

Schwartz-Shea, P. and Yanow, D. (2012) Interpretive Research Design: Concepts and Processes, London: Routledge. 
Smith, S. (1985), 'Groupthink and the Hostage Rescue Mission', British Journal of Political Science, 15/1, 117-123.

The Report of the Iraq Inquiry (2016) Her Majesty's Stationary Office, 6 July, available at http://www.iraqinquiry.org.uk/the-report/ (accessed 4 November 2016).

Walker, S.G. and Malici, A. (2011) US Presidents and Foreign Policy Mistakes, Stanford: Stanford University Press.

Wetherell, M., Taylor, S. and Yates, S.J. (2009) Discourse as Data: A Guide for Analysis, Milton Keynes: The Open University.

White, H. (1975) Metahistory: The Historical Imagination in Nineteenth-century Europe, London: The Johns Hopkins University Press.

White, H. (1992) The Content of the Form: Narrative Discourse and Historical Representation, London: The Johns Hopkins University Press.

Wyden, P. (1979) Bay of Pigs: The Untold Story, New York: Simon and Schuster.

Yanow, D. (2000) Conducting Interpretive Policy Analysis, London: SAGE.

Yanow, D. and Schwartz-Shea, P. (2014) Interpretation and Method: Empirical Research Methods and the Intepretive Turn, $2^{\text {nd }}$ edn, London: Routledge. 
